\title{
PARTIAL HYDATIDIFORM MOLE WITH A LIVE FETUS: A RARE ENTITY
}

Mounika Reddy Kakumanu1, G. Rama Krishna Reddy², M. James Prem Sagar³, K. Venkatram Reddy4, V. Ravinder Naik ${ }^{5}$

\section{HOW TO CITE THIS ARTICLE:}

Mounika Reddy Kakumanu, G. Rama Krishna Reddy, M. James Prem Sagar, K. Venkatram Reddy, V. Ravinder Naik. "Partial Hydatidiform Mole with a Live Fetus: A Rare Entity". Journal of Evolution of Medical and Dental Sciences 2015; Vol. 4, Issue 60, July 27; Page: 10590-10596, DOI: 10.14260/jemds/2015/1529

ABSTRACT: BACKGROUND: Gestational trophoblastic neoplasia (GTN) represents a spectrum of premalignant and malignant diseases that occur after abnormal fertilization.[1] GTN includes complete hydatidiform mole (CHM), partial hydatidiform mole (PHM), invasive mole, choriocarcinoma, and placental-site trophoblastic tumor (PSTT). CHM and PHM together account for $80 \%$ of all cases of GTN.

KEYWORDS: Molar pregnanacy, BETA-hcg, partial mole, gestational trophoblastic, Hydatidiform, villous hydrops.

\section{CASE REPORT:}

- In our case, a 27 yrs old G3P2L2 presented with vague abdominal pain.

- Vomiting -2 episodes.

- Amennorhea since 3 months.

- On ultrasound the fetus corresponded to 15 weeks 0 days with fetal heart rate of $142 \mathrm{bpm}$ with no external congenital abnormalities.

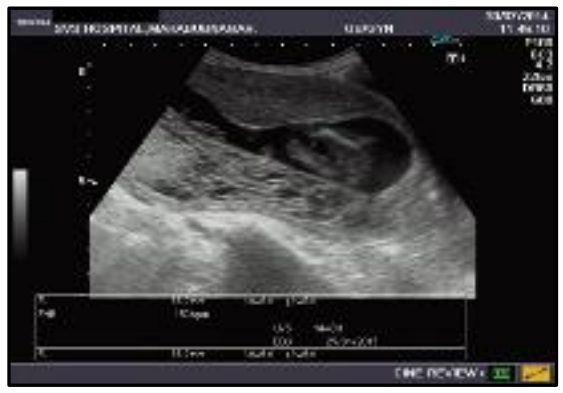

\section{Fig. 1}

- In fig-a, the placenta was fundo-posterior in position which was partly normal and partly interspersed with multiple variable sized cystic spaces (molar placenta).

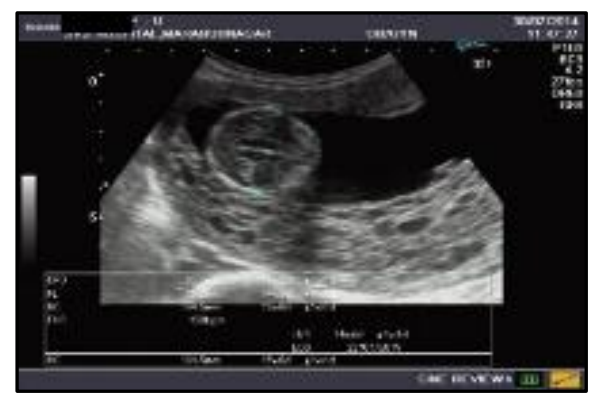

\section{Fig. 2}




\section{CASE REPORT}

- The cystic spaces are avascular on colour Doppler as shown in fig-b, and also noted with active fetal cardiac pulsations (FHR)-142 beats per minute.

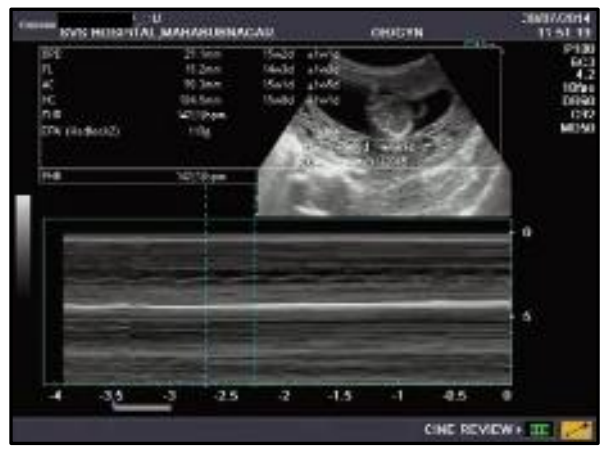

\section{Fig. 3}

\section{OTHER INVESTIGATIONS:}

\section{Pre evacuation HCG values:}

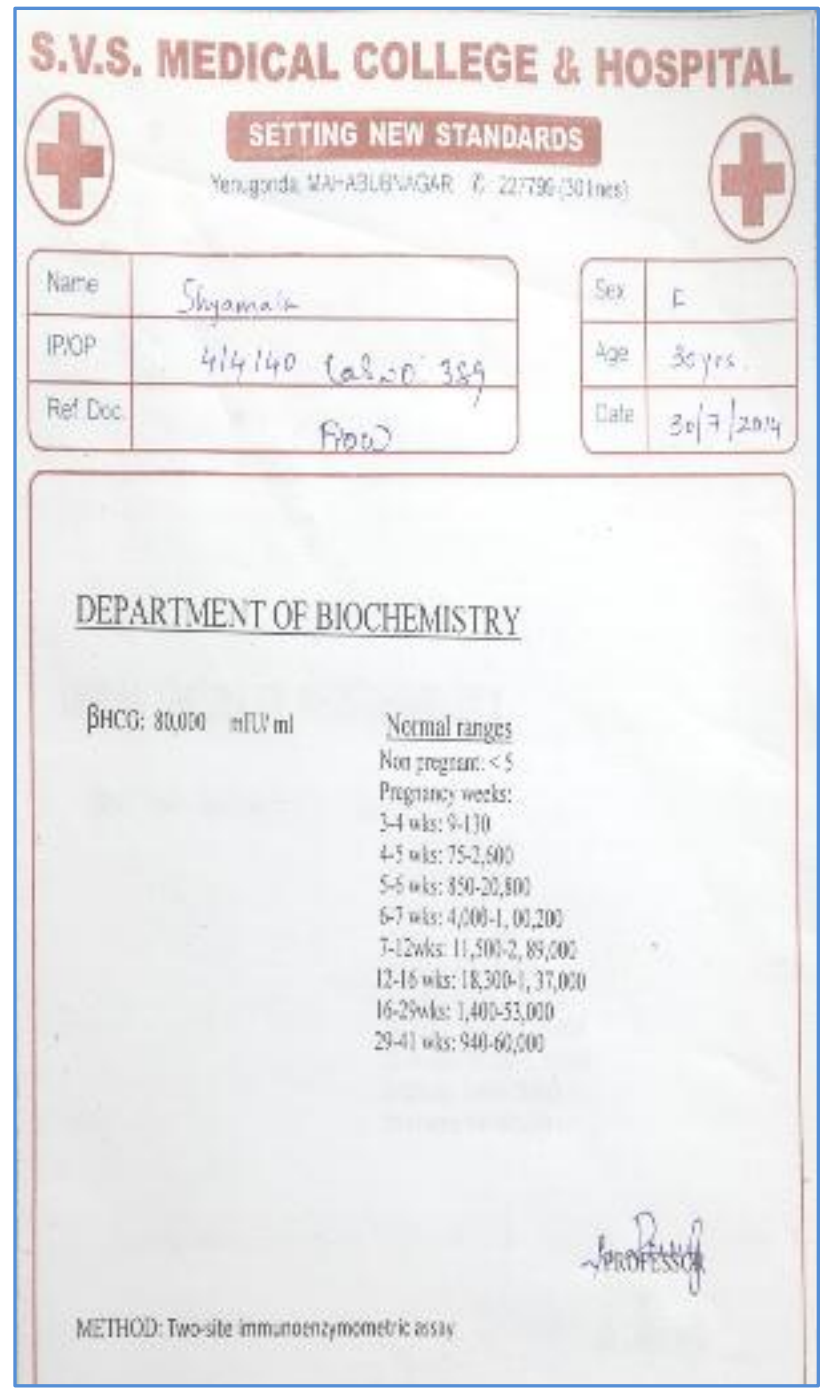




\section{Post evacuation HCG values:}

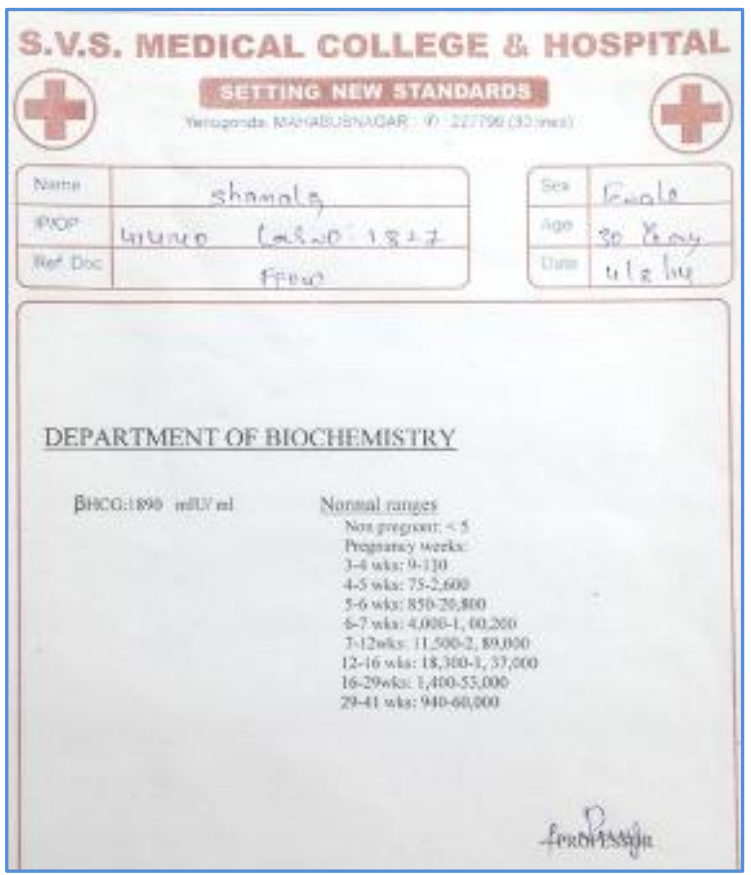

\section{Histopathological Correlation:}

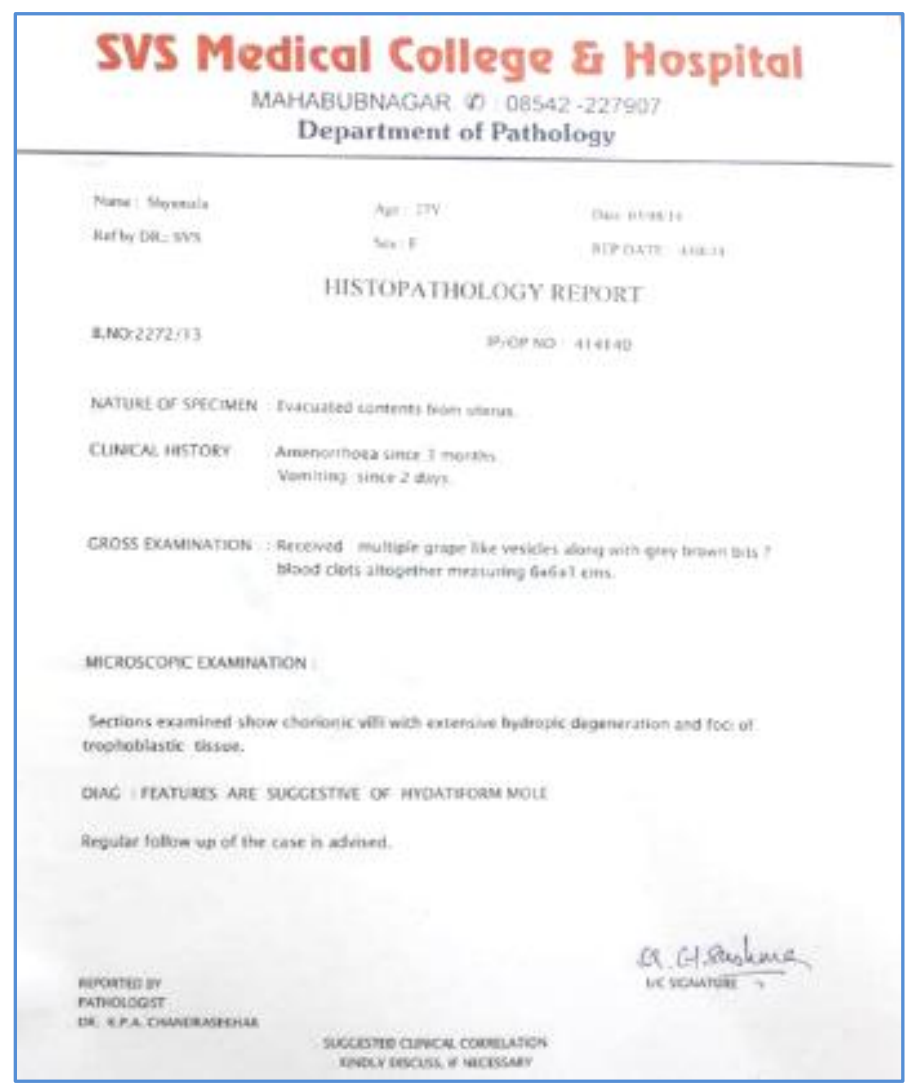




\section{Post-operative Clinical Macro-specimen showing a Fetus along with Molar Pregnancy:}

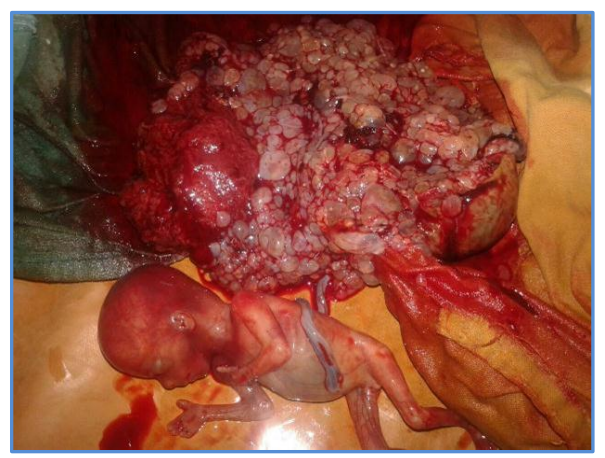

\section{Fig. 4}

- A live fetus of $150 \mathrm{gms}$ was delivered.

- The diagnosis of partial mole was followed up by beta Hcg pre $(80,000)$ and post evacuation (1890) and confirmed by histopathological examination.

- Partial hydatidiform mole (PHM) with a live fetus is a rare condition.

PHM is a histopathological entity characterized by focal trophoblastic hyperplasia with villous hydrops and identifiable fetal tissue.

\section{DISCUSSION:}

- Ultrasonography is the imaging investigation of choice to confirm the diagnosis of hydatidiform mole. A transabdominal and transvaginal imaging with transducers of highest frequency possible should be performed.[2,3,4,5,6] Clinical examination and beta-human chorionic gonadotropin (beta-hCG) determinations are the recommended initial tests for hydatidiform mole. It is characterised by its focal distribution, slower transformation, the presence of an embryo or fetus, and a triploid karyotype (70\% are 69 , XXY; $27 \%$ are 69 , XXX; $3 \%$ are 69 XYY). The extra set of chromosomes is often of paternal origin.

- Hydatidiform moles should be regarded as premalignant lesions because $15-20 \%$ of complete hydatidiform moles (CHMs) and 1\% of partial hydatidiform moles (PHMs) undergo malignant transformation into invasive moles, choriocarcinomas, or, in rare cases, placental-site trophoblastic tumors (PSTTs).[7,8]

- Performed by an interventional radiologist, selective embolization of the uterine artery is reported as a well-tolerated and effective treatment option for managing severe bleeding from residual uterine vascular malformations in patients with gestational trophoblastic tumors that have been treated.[9,10]

INVESTIGATION: Ultrasonography is the imaging investigation of choice for hydatidiform mole. The established roles for sonography include the following; $[11,12,13,14,15,16]$

1. Initial diagnosis.

2. Assessment of treatment responses.

3. Determination of invasion in malignant forms of gestational trophoblastic neoplasia.(GTN)

4. Determination of recurrent disease in malignant forms of GTN. 
COMPUTER TOMOGRAPHY, MRI: CT and/or MRI evaluation are not usually performed initially but may be used to determine if there is extension of molar tissue outside the uterus.(17) CT may show an enlarged uterus with areas of low attenuation, or hypoattenuating foci surrounded by highly enhanced areas in the myometrium.

MRI is indicated in patients with malignant forms of gestational trophoblastic neoplasia (GTN) for an assessment of tumor vascularity and of myometrial and parametrial extension.

\section{MRI findings may include the following:[18,19,20,21,22]}

1. Heterogeneous endometrial enlargement with several hyperintense foci that represent hydropic villi on T2-weighted imaging.

2. Focal tumor masses in the endometrium and/or myometrium.

3. Loss of uterine zonal anatomy (indistinctness of the endometrial-myometrial border).

4. Pathologic myometrial, endometrial, and parametrial vasculature characterized by dilated and tortuous vessels.

\section{DIFFERENTIAL DIAGNOSIS:}

1. Fetal demise with placental hydropic change: beta HCG levels are invariably low in this case.

2. Twin pregnancy with one normal twin and one complete hydatidiform mole: the normal twin usually has its own normal placenta.

3. Placental mesenchymal dysplasia.

Sonograms of partial hydatidiform mole (PHM) may show cystic changes similar to those of CHM but in a more focal distribution. The major distinguishing feature of PHM is embryonic tissue. These patients are prone to preterm labour and premature rupture of membranes (PPROM).

\section{REFERENCES:}

1. Green CL, Angtuaco TL, Shah HR, Parmley TH. Gestational trophoblastic disease: a spectrum of radiologic diagnosis. Radiographics. Nov 1996; 16(6): 1371-84.

2. Allen SD, Lim AK, Seckl MJ, et al. Radiology of gestational trophoblastic neoplasia. Clin Radiol. Apr 2006; 61(4): 301-13.

3. DeBaz BP, Lewis TJ. Imaging of gestational trophoblastic disease. Semin Oncol. Apr 1995; 22(2): 130-41.[Medline].

4. Dipi RM, Amin MS, Islam MN, Khan NA, Chaiti MM, Hossain MM. Comparison of transabdominal and transvaginal sonography in the evaluation of uterine mass with histopathological correlation. Mymensingh Med J. Jan 2013; 22(1): 69-74.

5. Unsal MA, Guven S. Complete hydatidiform mole coexisting with a live fetus. Clin Exp Obstet Gynecol. 2012; 39(2): 262-4.

6. Sasaki Y, Ogawa K, Takahashi J, Okai T. Complete hydatidiform mole coexisting with a normal fetus delivered at 33 weeks of gestation and involving maternal lung metastasis: a case report. J Reprod Med. Jul-Aug 2012; 57(7-8): 301-4.

7. Hurteau JA. Gestational trophoblastic disease: management of hydatidiform mole. Clin Obstet Gynecol. 2003; 46: 557-69.

8. Sebire NJ, Makrydimas G, Agnantis NJ, et al. Updated diagnostic criteria for partial and complete hydatidiform moles in early pregnancy. Anticancer Res. Mar-Apr 2003; 23(2C): 1723-8. 
9. Lim AK, Agarwal R, Seckl MJ, et al. Embolization of bleeding residual uterine vascular malformations in patients with treated gestational trophoblastic tumors. Radiology. Mar 2002; 222(3): 640-4.

10. Vogelzang RL, Nemcek AA, Skrtic Z, et al. Uterine arteriovenous malformations: primary treatment with therapeutic embolization. J Vasc Interv Radiol. Nov 1991; 2(4): 517-22.

11. Sebire NJ, Rees H, Paradinas F, et al. The diagnostic implications of routine ultrasound examination in histologically confirmed early molar pregnancies. Ultrasound Obstet Gynecol. Dec 2001; 18(6): 662-5.

12. Zhou Q, Lei XY, Xie Q, Cardoza JD. Sonographic and Doppler imaging in the diagnosis and treatment of gestational trophoblastic disease: a 12-year experience. J Ultrasound Med. Jan 2005; 24(1): 15-24.

13. Müngen E, Dundar O, Muhcu M, Haholu A, Tunca Y. Placental mesenchymal dysplasia associated with trisomy 13: sonographic findings. J Clin Ultrasound. Sep 2008; 36(7): 454-6.

14. Dighe M, Cuevas C, Moshiri M, Dubinsky T, Dogra VS. Sonography in first trimester bleeding. J Clin Ultrasound. Jul-Aug 2008; 36(6): 352-66.

15. Raga F, Bonilla F, Sanz-Cortés M, Bonilla-Musoles F. Three-dimensional inversion mode rendering in molar pregnancy. Ultrasound Obstet Gynecol. Mar 2008; 31(3): 362-3. [Medline].

16. Goldstein SR. Early detection of pathologic pregnancy by transvaginal sonography. J Clin Ultrasound. 1990; 18(4): 262-73.

17. Hong DG, Cho YL, Park IS, Lee YS. Chest computed tomography before evacuation of hydatidiform mole.Eur J Gynaecol Oncol. 2009; 30(2): 151- 4.

18. Barton JW, McCarthy SM, Kohorn EI, et al. Pelvic MR imaging findings in gestational trophoblastic disease, incomplete abortion, and ectopic pregnancy: are they specific?. Radiology. Jan 1993; 186(1): 163-8.

19. Hricak H, Demas BE, Braga CA, et al. Gestational trophoblastic neoplasm of the uterus: MR assessment.Radiology. Oct 1986; 161(1): 11-6.

20. Imaoka I, Sugimura K, Masui T, et al. Abnormal uterine cavity: differential diagnosis with MR imaging.Magn Reson Imaging. Dec 1999; 17(10): 1445-55.

21. Powell MC, Buckley J, Worthington BS, Symonds EM. Magnetic resonance imaging and hydatidiform mole.Br J Radiol. Jun 1986; 59(702): 561-4.

22. Preidler KW, Luschin G, Tamussino K, et al. Magnetic resonance imaging in patients with gestational trophoblastic disease. Invest Radiol. Aug 1996; 31(8): 492-6. 


\section{CASE REPORT}

\section{AUTHORS:}

1. Mounika Reddy Kakumanu

2. G. Rama Krishna Reddy

3. M. James Prem Sagar

4. K. Venkatram Redddy

5. V. Ravinder Naik

\section{PARTICULARS OF CONTRIBUTORS:}

1. Post Graduate Final Year Student, Department of Radiology, SVS Medical College \& Hospital, Yenugonda, Mahabub nagar.

2. Professor, Department of Radio-diagnosis, SVS Medical College \& Hospital, Yenugonda, Mahabubnagar.

3. Assistant Professor, SVS Medical College \& Hospital, Yenugonda, Mahabubnagar.

\section{FINANCIAL OR OTHER}

COMPETING INTERESTS: None
4. HOD \& Professor, Department of Radiology, SVS Medical College \& Hospital, Yenugonda, Mahabubnagar.

5. Post Graduate Final Year Student, Department of Radiology, SVS Medical College \& Hospital, Yenugonda, Mahabub nagar.

\section{NAME ADDRESS EMAIL ID OF THE CORRESPONDING AUTHOR:}

Dr. M. James Prem Sagar, Assistant Professor, Department of Radiology, SVS Medical College \& Hospital, Yenugonda, Mahabubnagar-509001. E-mail: premsvsraddoc@gmail.com

Date of Submission: 22/06/2015. Date of Peer Review: 23/06/2015. Date of Acceptance: 20/07/2015. Date of Publishing: 27/07/2015. 